短 報

\section{異なった電子顕微鏡標本作製法の 石綿繊維の元素組成への影響}

Effects of Different Preparation Methods for Electron Microscopy on Elemental

Compositions of Asbestos Fibers

Key words : asbestos ; elemental composition ; preparation method

生体試料に含きれる石綿瀻維を電子影微鏡（電顕）で 分析するには，共存する物質をできるだけ除去して石綿 瀻維を残寸前処理が必要である．前処理には湿式灰化法 や低温灰化法など多くの方法が試みられている11，著者 らは, 先にヒトの肺組織中石綿䋐維の電顕䚌察用標本を Gylseth らの低温灰化法2) 之同時に，一部の試料につい ては Smith らの湿式灰化法帛です作整 し, KEVEX 7000-Q 形エネルギー分散形 X 線分析システム付 H-800 形電子顕徽鏡（分析電顕）により瀻維の元素組成分析を 行った、その結果，著者らがクリソタイルと判定した石

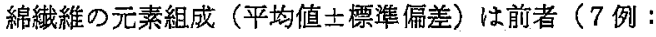
$n=63)$ では $\mathrm{Mg} 36 \pm 11 \%, \mathrm{Si} 60 \pm 11 \%, \mathrm{Fe} 4 \pm 5 \%$ て あったのK対して後者（3例： $n=36$ ) では $\mathrm{Mg} \mathrm{43 \pm 8}$ $\%$, Si $55 \pm 8 \% ， \mathrm{Fe} 2 \pm 4 \%$ であり，Mg 於よび Si の 值は有意 $(p<0.05)$ 飞異なっていた。クリッタイルは 酸性条件では緀維から $\mathrm{Mg}$ が溶出することが知られてお り4,5)，次巠塩素酸ナトリウム $(\mathrm{NaClO})$ によっても $\mathrm{Mg}$ と Si の割合が变化するといら報告6るある。市た，石 綿瀻維の元素組成と発ガン性に関連して Mg 含有率の低 いクリンタイルでは発ガン性が低下するといら報告7,8 るあるので，生体組織中に存在する石綿織維の元素組成 を変化させず把握することは重要である。しかし，実 際の前処理に即した条仵での石綿瀻維の元索組成の変化 については著者らの知る限りでは報告がない。そこで生 体試料の電頭標本作製時の前処理でよく用いられる酸や アルカリならぴにその使用条件が，現在工業的に使用さ れ，一般環境や生体組織からも検出される石綿織維 3 種 類（クリソタイル，クロシドライト，アモサイト）の元 素組成に及侍す影響について検討した。

\section{実 験}

1. 装置：KEVEX 7000-Q 型エネルギー分散型 $\mathrm{X}$ 楾 分析システム付 $\mathrm{H}-800$ 型電子顕微鏡

2. 処理条件の選定：酸亡アルカリの種類と浱度は， 現在比校的よく使用されている前処理方法から選んだ
アルカリ溶液としては $\mathrm{NaClO}^{3}$ と $40 \%$ 水酸化カリウム $(\mathrm{KOH})^{97}$ ，酸溶液 乙しては濃塩酸 $(12 \mathrm{~N})^{10)}$ 之希塩酸 $(0.5 \mathrm{~N})^{2)}$ を用いた．対照実験は蒸留水で行った．放置 時間は低温灰化法での灰化物の愁溜万過に要する時間视 らびに湿式灰化法での分解時間を考虑して 30 分間々 48 時間とした。

3. 試薬：クリソタイル，クロシドライトおよびアモ サイト性日本石綿協会より入手したものを使用した。 $\mathrm{NaClO}$ は有效塩素約 $10 \%$ のものを，KOH ならび塩 酸は特級試菜 (片山化学) を使用した。

4. 操作 : 共栓付 $200 \mathrm{ml}$ 三角フラスコに石綿織維的 $0.5 \mathrm{mg}$ ，酸またはアルカリを $100 \mathrm{ml}$ 泒加して室温で 5 分間超音波分散した. 30 分間または 48 時間室温で放置 した後，再度室温で 5 分間超音波分散してニニークリホ アフィルター（孔径 $0.2 \mu \mathrm{m}$, 直径 $47 \mathrm{~mm}$, 野村マイク ロサイェンス)で吸引ろ過した。フィルターを炭素蒸着 後，電顥用グリッド (200 mesh, Ni 製, VECO 社) 上 に載せ,クロロホルム蒸気で薄膜化した。石綿瀻維の元 素組成は 1 試料当たり 20 本饮ついて求めた。

5. 検定方法 : 各元素の占める百分率の平均值の差を $t$-検定によって険定した。

\section{結 果}

Table 1Kクリソタイル, Table 2 にクロシドライト, Table 3 にアモサイト蒸留水， $\mathrm{NaClO}, 40 \% \mathrm{KOH}$, $12 \mathrm{~N}$ 塩酸ならびに $0.5 \mathrm{~N}$ 塩酸に 30 分間をたは 48 時間 放置した時の元素組成の変化を示した.

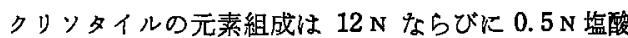
では 30 分間放置で既に有意な変化を生した．蒸留水や $\mathrm{NaClO}, \mathrm{KOH}$ では 48 時間放置後でも有意な变化は見ら れなかった.クロシドライトならびにつモサイトの元素 組成はいずれの条件でも有意な变化を示さなかった。 た電顕像の肉眼観察ではいずれの種類の石綿㵶維にも前 処理によると思方れる形状の変化は見られなかった。

分析した瀻維の直径はクリソタイル $0.20 \pm 0.18 \mu \mathrm{m}$ $(n=200)$, クロシドライト $0.26 \pm 0.18 \mu \mathrm{m}(n=200)$, アモサイト $0.28 \pm 0.20 \mu \mathrm{m}(n=200)$ であった. $12 \mathrm{~N}$ 塩酸に 48 時間放置したクリソタイルの元素組成法, 直 径 $0.1 \mu \mathrm{m}$ をこえる㵶維 $(n=12: 0.27 \pm 0.16 \mu \mathrm{m})$ て は $\mathrm{Mg} 29 \pm 7 \%$, Si $69 \pm 7 \%, \mathrm{Fe} 3 \pm 2 \%$ なのに対して, 直径 $0.1 \mu \mathrm{m}$ 以下の緎維 $(n=8: 0.07 \pm 0.03 \mu \mathrm{m})$ で性 $\mathrm{Mg} 21 \pm 8 \%$, Si $75 \pm 7 \%, \mathrm{Fe} 5 \pm 1 \%$ で，細い絨維の 活うが $\mathrm{Mg}$ の減少が大きかった。 しかし対照実験では 直径炕よる元素組成の違いは見られなかった。クロシド ライトとアモサイトの元素組成は直径関係なくほぱー 定であった。 


\section{考 察}

Gylseth らの方法は，生体試料を乾 燥・低温灰化後, $10 \%$ エチルフルこ 一ルを含む $0.5 \mathrm{~N}$ 塩酸で灰化物を惩濁 分散させ，吸引ろ過を行っている. Smith らの方法は， NaClO で生体試 料中の有機物を分解し，クロロホルム と $50 \%$ エチルフルコールによるター ル分等の抽出除去後に得られた残塩を 再び 95\% ェテルアルコールで喺濁分 散させ，吸引ろ過を行っている．今回 の実験結果では, クリンタイルの元素 組成は $\mathrm{NaClO}, \mathrm{KOH}$ および蒸溜水化 よる処理条件では有意な変化を示ざず に，塩酸酸性条件での処理によってそ の元素組成が有意に変化していたの

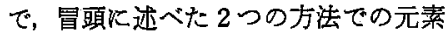
組成の違いは Gylseth らの方法で使用 されている $0.5 \mathrm{~N}$ 塩酸に起因すると考 えられた。

生体内に存在するクリソタイルの $\mathrm{Mg}$ 含有率は一般に 低いことが報告されている4,11)が，電顕標本作製時に酸 性条件を使用するとクリソタイルの $\mathrm{Mg}$ 含有率がさらに 低下する，分析電顕による石綿瀻維の同定は緘維の形状 と元素組成に基づいて行らので， $\mathrm{Mg}$ 含有率の低下した クリソタイルは㵶維状または棒状でから類似の元素組成 を示すタルク ( $\mathrm{Mg}: 39 \%$, Si : 61\%) ${ }^{123}$ やセピみライト $(\mathrm{Mg}: 37 \%, \mathrm{Si}: 63 \%)^{12)}$ との区別が一層難しくなる. 一方, クシドライトならびにアモサイトの元素組成は， 今回の実験結果では電顕標本作製時に通常用いられる前 処理条件では有意な変化を示さなかった。

したがって石綿繊維の分析するための電顕標本作製時 の前処理では酸性条件を避けて行うのが望をしいと考え られる.

\section{文 献}

1) Hans Weill, ed. Occupational lung diseases: research approaches and methods. New York Marcel Dekker Inc, 1981 : 199-206.

2) Gylseth B, Mowe G, Wannag A. Fibre type and concentration in the lungs of workers in an asbestos cement factory. Br J Ind Med 1983; 40 : 375-379.

3) Smith MJ, Nayler B. A method for extracting ferruginous bodies from sputum and pulmonary tissue. Am J Clin Pathol 1972; $58: 250-254$.

4) Kohyama N, Kawai $K$, Aita $S$, et al. Quantitative chemical analysis of chrysotile fibrils in rat lung tissue by analytical electron microscopy. Ind Health $1977 ; 15: 159-171$.

5) Seshan K. How are the physical and chemical properties of chrysotile asbestos altered by a 10 . year residence in water and up to 5 days in simulated stomach acid? Environ Health Perspect $1983 ; 53: 143-148$.

6) Warnock ML, Prescott BT, Kuwahara TJ. Nurn. bers and types of asbestos fibers in subjects with pleural plaques. Am Assoc Pathol 1982; 109 : 3746.

7) Morgan A, Davis, P, Wagner JC, et al. The biological effects of magnesium-leached chrysotile asbestos. Br J Exp Pathol 1977; $58: 465-473$.

8) Monchaux G, Bignon J, Jaurand $M C$, et al. Mesotheliomas in rats following inoculation with acid-leached chrysotile asbestos and other mineral fibers. Carcinogenesis $1981 ; 2: 229-236$

9) Ashcroft T, Heppleston AG. The optical and electron microscopic determination of pulmonary asbestos fiber concentration and its relation to the human pathological reaction. J Clin Pathol 1973; 26:224-234.

10) Guest L. The recovery of dust from formalinfixed pneumoconiotic lungs: a comparison of the methods used at S.M.R.E. Ann Occup Hyg 1976 $19: 37-47$.

11) Langer AM. Chemical characterization of asbestos body cores by electron microprobe analysis. J Histochem Cytochem 1972; $20: 723-734$.

12）須藤談話会，編. 土をみつめる一粘土鉱物の世界一、東 京：三共出版，1986:206-207.

酒井 潔*，久永直見**，竹内康浩**

* 名古屋市郝生研究所

** 名古晊大学医学部徫生学教室

Kiyoshi SAKal,* Naomi Hisanaga**

and Yasuhiro TAKeUCHI**

* Nagoya City Health Research Institute, 1-11, Hagiyama-cho, Mizuho-ku, Nagoya, 467 Japan

** Department of Hygiene, Nagoya University School of Medicine

昭和 62 年 1 月 17 日受付

通信先：酒井むて, Reprint requests to K. Sakai 